\title{
Comparative study of element contents in seven isolates of entomopathogenic nematodes
}

\author{
A. M. A. Meligy ${ }^{1,2}$
}

\begin{abstract}
Little is known about element contents in the entomopathogenic nematodes despite their vital role in the growth and development of all organisms. Ten element contents of seven nematode isolates were determined. No significant differences were observed in concentrations of aluminum (Al), chromium ( $\mathrm{Cr}$ ), and lead $(\mathrm{Pb})$ among all the studied nematode isolates, while significant differences of cadmium (Cd), selenium (Se), zinc (Zn), and manganese (Mn) concentrations among isolates were found. All isolates related to Heterorhabditidae family contained significantly higher copper (Cu), iron (Fe), and cobalt (Co) concentrations than isolates related to Steinernematidae family of entomopathogenic nematode (EPN). In all of tested isolates, the content of Cu was the highest and that of Se was the lowest. The concentrations of the studied elements were in the following descending order: $\mathrm{Cu}>\mathrm{Fe}>\mathrm{Co}>\mathrm{Mn}>\mathrm{Zn}>\mathrm{Pb}>\mathrm{Cr}>\mathrm{Cd}>\mathrm{Al}>\mathrm{Se}$. It is suggested that Photorhabdus bacteria associated with Heterorhabditis spp. of EPN accumulate $\mathrm{Cu}$, Fe, and Co for activation of their metalloenzymes to enhance their virulence potential.
\end{abstract}

Keywords: Entomopathogenic nematodes, Heterorhabditis spp., Steinernema spp., Egyptian isolates, Elements

\section{Background}

Egyptian orchards are inhabited by diverse and abundant communities of native entomopathogenic nematodes (EPNs) of the families Steinernematidae and Heterorhabditidae, which have excellent potential as biological control agents against numerous insect pests. Advantages of EPNs as one biocontrol agents include the wide range of their host insects, ability to seek a host actively, fast insect killing, fast breeding, and no hazard for the environment or higher animals, as well as a possibility of their formulation, storing, and simple application (Jaworska and Gorczyca, 2002). The original vitality of the infective stage of nematode is one of the important factors that affects the field activity of EPNs. Many elements such as copper $(\mathrm{Cu})$, iron $(\mathrm{Fe})$, cobalt $(\mathrm{Co})$, selenium $(\mathrm{Se})$, and zinc $(\mathrm{Zn})$ occur in trace amounts in living organisms

Correspondence: amelegi@kfu.edu.sa; melegi_a@hotmail.com

${ }^{1}$ Physiology Department, Plant Protection Research Institute PPRI, Agricultural Research Center ARC, Giza, Egypt

${ }^{2}$ Department of Clinical studies, College of Veterinary Medicine, King Faisal University, Hofuf, Saudi Arabia 
elements are very small and determined the physiological state and vitality of IJs of EPN.

In the present study, ten element levels in nematode IJs of five geographically different Egyptian isolates of Steinernematidae and Heterorhabditidae families were determined. Also, element contents of IJs from two commercially relevant nematode strains were determined for comparison. This will provide detailed information on the degree of variation in element levels of these nematodes which would mean important progress on the road of improvement of EPN as an effective biocontrol agent and leading to a better understanding of the possible roles of metals in their physiology.

\section{Materials and methods}

\section{Nematode populations}

Five EPN isolates collected randomly from several locations of five Egyptian governorates that maintained at the Pest Physiology Department, Plant Protection Research Institute, Giza, Egypt. Also, two imported commercial nematode species were analyzed for their element composition (Table 1). Species of the isolated populations were identified using morphological and molecular tools (Nguyen, 2007). Element composition of $S$. carpocapsae isolates was compared to $S$. carpocapsae (all strain) extracted from the commercial product Ecomask (BioLogic, Inc., PA, USA). Due to unavailability of commercial products of $H$. indica, element composition of its isolates was compared to that of the closely related species, H. bacteriophora (HP88 strain), extracted from the commercial product Heteromask (BioLogic, Inc., PA, USA).

\section{Nematode culture and preparation}

All populations were cultured several times at 1- to 2month intervals using the last instar larvae of G. mellonella $\mathrm{L}$. larvae at $25^{\circ} \mathrm{C}$ following isolation to ensure that their contents of elements are not due to field-adapted traits. Freshly harvested IJs were rinsed in deionized water, three times, and the number of IJs in each sample was determined by counting the number of nematodes in five droplets (5 $\mu \mathrm{l}$ each). Harvested IJs were concentrated and vacuum filtered, and their wet weight was measured. Three replicates from each nematode isolate were prepared for metal analysis. Prior to sampling for element analysis, nematode viability and virulence were checked according to the method described by Kaya and Stock (1997) and only viable and highly virulent IJ stocks were used. Nematode IJs were considered viable and highly virulence when both their survival rate and virulence percent against G. mellonella larvae were $>95 \%$ (Kaya and Stock, 1997).

\section{Metal analysis}

Ten elements: cadmium $(\mathrm{Cd})$, aluminum $(\mathrm{Al})$, zinc $(\mathrm{Zn})$, iron $(\mathrm{Fe})$, selenium $(\mathrm{Se})$, chromium $(\mathrm{Cr})$, manganese $(\mathrm{Mn})$, cobalt $(\mathrm{Co})$, copper $(\mathrm{Cu})$, and lead $(\mathrm{Pb})$, were analyzed in IJ samples according to the procedure described by El-Bahr and Abdelghany (2015).

\section{Digestion samples}

Mars Xpress (CEM-MARS Express ${ }^{\oplus}$, Matthews, NC, USA) Microwave Digestion System was used. All the digestion procedures were using Teflon reaction vessels $5 \mathrm{ml}$ accordance to USEPA method 3051(El-Bahr and Abdelghany, 2015). A weight of $0.25 \mathrm{~g}$ of each nematode sample was placed into separate digestion vessels with $3 \mathrm{ml}$ of concentrated nitric acid $\left(\mathrm{HNO}_{3} 65 \%\right)$ and $2 \mathrm{ml}$ of hydrogen peroxide $\left(\mathrm{H}_{2} \mathrm{O}_{2}\right.$ 30\%). Double-distilled water were used to clean all samples and remove any contaminate particles. The samples were allowed to the method of digestion with ramp at $200{ }^{\circ} \mathrm{C}$ for 15 min and cooled down for $5 \mathrm{~min}$. The digested nematode samples were diluted by $25 \mathrm{ml}$ Millipore deionized water as a total volume.

\section{Instruments}

The filtrates of digested nematode samples were analyzed by atomic absorption spectrometry (AAS), according to the method mentioned by Pakshirajan et al. (2013). The determination of $\mathrm{Al}, \mathrm{Cu}, \mathrm{Zn}, \mathrm{Fe}$, and $\mathrm{Mn}$ was carried out by using flame atomic absorption spectrophometer, Shimadzu AA-6800 model. The absorbance was obtained by adjusting the

Table 1 Locality, crop, and source of entomopathogenic nematode populations used in the present study

\begin{tabular}{lllll}
\hline Species & Population & Geographic location & Crop & Source $^{\text {a }}$ \\
\hline Heterorhabditis bacteriophora & HP88 & USA & Commercial product & BioLogic, Inc., USA \\
Heterorhabditis indica & EGAZ1 & Suez, Egypt & Nectarines & Soil \\
Heterorhabditis indica & EGAZ2 & El-kasasein, Ismailia, Egypt & Mango & Soil \\
Heterorhabditis indica & EGAZ3 & El-kasasein, Ismailia, Egypt & Palm & Soil \\
Steinernema carpocapase & All & USA & Commercial product & BioLogic, Inc., USA \\
Steinernema carpocapase & EGAZ9 & Belbeis, Sharkia, Egypt & Mango & Soil \\
Steinernema carpocapase & EGAZ10 & Qaha, Qalyubiya, Egypt & Lettuce & Soil \\
\hline
\end{tabular}

${ }^{a}$ Nematodes were isolated from soil using the last instar larvae of Galleria mellonella as bait 
cathode lamps at the operation conditions shown in Table 2 as previously described by El-Bahr and Abdelghany (2015). Graphite furnace (GFA-EX7) atomic absorption spectrophometer (Shimadzu, Koyoto, Japan) was used for the determination of $\mathrm{Pb}$, $\mathrm{Se}, \mathrm{Cd}, \mathrm{Cr}$, and $\mathrm{Co}$. The graphite furnace program for determination of $\mathrm{Se}, \mathrm{Co}, \mathrm{Al}, \mathrm{Pb}$, and $\mathrm{Cd}$ by GFAEX7 and the instrumental setting were similar to that described by El-Bahr and Abdelghany (2015) (Table 3). Standard stock solutions of the studied elements were prepared with deionized water. To avoid error, a slight instrumental drift monitored by analyzing calibration standards at regular intervals during analysis alongside samples was taken into account. Full quantitative analysis mode was applied for all measurements. Calibration curves were obtained for different concentrations of standard solutions prepared from $1000 \mathrm{mg} / \mathrm{l}$ stock solution (Merck, Germany).

\section{Analytical quality control}

To appropriate quality assurance and the efficiency of procedures such as recovery of the elements was determined. Three samples of nematodes were spiked with the amount of standard solution containing $3 \mu \mathrm{g} / \mathrm{g}$ of each element considered in the present study. Similar nematode samples spiked with the same amount of deionized water without elements were used as control. The samples were then subjected to the digestion instrument procedure and analyzed for metal concentrations to establish confidence in the accuracy and reliability of data generated (Table 4).The accuracy of certified elements varied between 87 and 93\%, which can be considered a reliable analysis (El-Bahr and Abdelghany, 2015).

\section{Statistical analysis}

The element contents of the studied nematode isolates were expressed as picograms per infective juvenile (pg/II). All data were analyzed for analysis of variance (ANOVA). The means were separated by Duncan's multiple-range test for significance at $P<0.05$ using the computer software package of CoStat for windows (Costat, 2008). Results were recorded as mean \pm standard deviation (SD).

\section{Results and discussion}

The ANOVA analysis of the concentrations of elements among the studied nematode isolates revealed insignificant differences in their contents of $\mathrm{Al}, \mathrm{Cr}$, and $\mathrm{Pb}$ (Table 5). For the remaining seven elements, patterns of bioaccumulation in IJs differed depending on the isolate, the species, and the family. Co was significantly higher in H. bacteriophora (HP88) and H. indica EGAZ3 than the other five isolates (Table 5). The results showed that IJs of $S$. carpocapsae (EGAZ9) contained significantly lower amounts of Se $(0.1 \pm 0.035 \mathrm{pg} / \mathrm{IJ})$ than $H$. indica (EGAZ1), H. bacteriophora (HP88), H. indica (EGAZ2), and S. carpocapsae (all) $(0.22 \pm 0.06,0.19 \pm 0.05,0.14 \pm$ 0.05 , and $0.16 \pm 0.045 \mathrm{pg} / \mathrm{IJ}$, respectively). IJs of $H$. bacteriophora (HP88) isolates contained significantly higher amounts of $\mathrm{Zn}$ than all other isolates (Table 5), while the highest concentration of Mn was detected in H. indica (EGAZ2) $(27.5 \pm 6.0$, (Table 5). Also, Mn concentration was significantly higher in $H$. bacteriophora (HP88) than both $H$. indica (EGAZ2) and $H$. indica (EGAZ2) $(15.1 \pm 5.0$ vs $6.1 \pm 3.0$ and $4.0 \pm 2.0 \mathrm{pg} / \mathrm{IJ}$, respectively). In addition, the imported strain of $S$. carpocapsae (all) contained significantly lower concentration of Mn than local S. carpocapsae (EGAZ9 and 10) $(6.5 \pm 2.5$ vs $15.1 \pm 3.8$ and $16.3 \pm 3.2 \mathrm{pg} / \mathrm{IJ}$, respectively). Table 5 showed that the four tested heterorhabditid isolates contained comparable concentrations of $\mathrm{Co}$, $\mathrm{Fe}$, and $\mathrm{Cu}(P>0.05)$. Also, comparable concentrations of $\mathrm{Co}, \mathrm{Fe}$, and $\mathrm{Cu}(P>0.05)$ were detected in IJs of the three tested steinernematid isolates. The differences in $\mathrm{Co}, \mathrm{Fe}$, and $\mathrm{Cu}$ concentrations between heterorhabditid and steinernematid isolates were significant $(P>0.05)$. In all of the tested isolates, the content of $\mathrm{Cu}$ was the highest and that of Se was the lowest. The concentrations of the studied elements decreased in the following order: $\mathrm{Cu}>\mathrm{Fe}>\mathrm{Co}>\mathrm{Mn}>\mathrm{Zn}>\mathrm{Pb}>\mathrm{Cr}>\mathrm{Cd}>\mathrm{Al}>\mathrm{Se}$. Comparing to the main concentrations of each element of the four tested heterorhabditid isolates with those of the three tested steinernematid isolates indicated that concentrations of $\mathrm{Cu}, \mathrm{Fe}$, and $\mathrm{Co}$ were significantly higher in Heterorhabditidae family than that in Steinernematidae family, whereas the concentrations of the remaining seven elements were comparable with a lack of statistical significances (Figs. 1 and 2). The previously mentioned data were also calculated as $\mathrm{pg} / \mathrm{g}$ nematode wet body weight

Table 2 Flame atomic absorption spectrophotometer (FAAS) operating method conditions

\begin{tabular}{llllll}
\hline Conditions & Aluminum $(\mathrm{Al})$ & Zinc $(\mathrm{Zn})$ & Iron $(\mathrm{Fe})$ & Manganese $(\mathrm{Mn})$ & Copper $(\mathrm{Cu})$ \\
\hline Wavelength $(\mathrm{nm})$ & 309 & 213.9 & 239.6 & 257.6 & 324.8 \\
Slit width $(\mathrm{nm})$ & 0.2 & 0.5 & 0.5 & 0.2 & 0.2 \\
Sensitivity $(\mu \mathrm{g} / \mathrm{ml})$ & 0.05 & 0.008 & & 0.05 & 0.014 \\
Flame type & Air-acetylene & & & \\
\hline
\end{tabular}


Table 3 Programs of heating method for chromium (Cr), cadmium (Cd), cobalt (Co), lead (Pb), and selenium (Se) in graphite furnace atomic absorption spectrophotometer (GFAAS)

\begin{tabular}{|c|c|c|c|c|c|c|c|c|}
\hline \multirow[t]{2}{*}{ Steps } & \multicolumn{5}{|c|}{ Temperature $\left({ }^{\circ} \mathrm{C}\right)$} & \multirow[t]{2}{*}{$\operatorname{Ramp}(\mathrm{s})$} & \multirow[t]{2}{*}{ Hold(s) } & \multirow{2}{*}{$\begin{array}{l}\text { Argon flow rate } \\
\left.(\mathrm{ml} \mathrm{min})^{-1}\right)\end{array}$} \\
\hline & $\mathrm{Cd}$ & $\mathrm{Cr}$ & $\mathrm{Pb}$ & Co & Se & & & \\
\hline Drying 1 & 150 & 150 & 150 & 150 & 150 & 5 & 20 & 250 \\
\hline Drying 2 & 200 & 200 & 200 & 200 & 200 & 5 & 15 & 250 \\
\hline Pyrolysis & 500 & 1600 & 800 & 1000 & 1200 & 10 & 20 & 250 \\
\hline Atomization & 1800 & 2300 & 2000 & 2300 & 2000 & 0 & 5 & 0 \\
\hline Clean-out & 2200 & 2500 & 2200 & 2600 & 2450 & 1 & 3 & 250 \\
\hline
\end{tabular}

and showed the same trend of significance of pg/IJ; thus, the data were not shown to not duplicate the results.

Many elements occur in very small amounts in living matter. While at minute concentrations, elements, particularly the first row transition metals such as manganese, iron, copper, cobalt, and zinc, were essentially for the growth and development of organisms, they can be toxic at higher concentrations. As only a few literature is available about the trace element profile in EPN, and as the IJs analyzed in the present study were viable and have an excellent virulence, data recorded here may not only serve as baseline value and reference data for natural level of elements in nematode but also give some indication of the nematode safe levels of such elements. To this end, values of the measured element values measured in the IJs were compared not just among species and isolates but also as a comparison between the two main EPN families (Steinernematidae and Heterorhabditidae).

Table 4 The recovery of elements from digested nematode samples

\begin{tabular}{llll}
\hline Elements & $\begin{array}{l}\text { Concentrations of } \\
\text { metal added } \\
(\mathrm{mg} / \mathrm{kg})\end{array}$ & $\begin{array}{l}\text { Concentrations } \\
\text { of metal } \\
\text { recovered } \\
(\mathrm{mg} / \mathrm{kg})\end{array}$ & Recovery (\%) \\
\hline Selenium (Se) & 3 & 2.8 & 93.3 \\
Cobalt (Co) & 3 & 2.8 & 93.3 \\
Iron (Fe) & 3 & 2.7 & 90 \\
Manganese (Mn) & 3 & 2.7 & 90 \\
Aluminum (Al) & 3 & 2.6 & 86.7 \\
Cadmium (Cd) & 3 & 2.8 & 93.3 \\
Copper (Cu) & 3 & 2.6 & 86.7 \\
Zinc (Zn) & 3 & 2.8 & 93.3 \\
Lead (Pb) & 3 & 2.8 & 93.3 \\
Chromium (Cr) & 3 & 2.7 & 90 \\
\hline
\end{tabular}

$\mathrm{Al}, \mathrm{Cr}$, and $\mathrm{Pb}$ have mainly been considered as pollutant and were presented in all of the studied nematode isolates in low concentrations that could reflect their level in nematode environment in the laboratory (such as water and food sources used in their cultures). $\mathrm{Cd}$, Se, and $\mathrm{Mn}$ are part of several macromolecules and considered as essential elements for many organisms (Nachev et al., 2013). While Mn has proved to possess many positive effects on IJs of $S$. carpocapsae and $H$. bacteriophora, the roles of $\mathrm{Cd}$ and Se in EPN biology are yet unknown (Jaworska and Gorczyca, 1993, 2002, 2009).

Significant differences were observed in this study in concentrations of $\mathrm{Cd}, \mathrm{Se}$, and $\mathrm{Mn}$ not only among different species of the same family or among the imported and the local populations of the same species but also among isolates of the same species from adjacent Egyptian locality. There was a significant difference in $\mathrm{Mn}$ concentration between $H$. bacteriophora (HP88) and H. indica (EGAZ2) (belong to the same family), between the imported S. carpocapsae (all) and the local S. carpocapsae (EGAZ9 and 10), and between $H$. indica (EGAZ2) and $H$. indica (EGAZ3) (both isolated from Ismailia governorate). The variations in element concentrations could be due to active uptake of $\mathrm{Cd}$, Se, and $\mathrm{Mn}$ by nematodes and a genetic component but not due to different environmental conditions as all the studied isolates were cultured several times in the laboratory under the same conditions.

In contrast to our results, $\mathrm{Cu}$ was reported to be considerably toxic for IJs of EPN (Jaworska and Gorczyca, 2002; Sun et al., 2016). Sambongi et al. (1999) reported that nematodes have elaborated sensorial equipment, including receptors for copper ions, which enables them to avoid their intake. Therefore, it was surprising to discover that $\mathrm{Cu}$ was the most abundant element in all nematode isolates in our study and its concentration was the highest among all the other studied elements. However, 
Table 5 Concentration of elements in infective juveniles (IJ) of the studied nematode species and/or isolates (concentration reported as mean picograms per IJ \pm standard deviation)

\begin{tabular}{llllllll}
\hline & $\begin{array}{l}\text { H. bacteriophora } \\
\text { (HP88) }\end{array}$ & $\begin{array}{l}\text { H. indica } \\
(\text { EGAZ1) }\end{array}$ & $\begin{array}{l}\text { H. indica } \\
\text { (EGAZ2) }\end{array}$ & $\begin{array}{l}\text { H. indica } \\
\text { (EGAZ3) }\end{array}$ & $\begin{array}{l}\text { S. carpocapsae } \\
\text { (all) }\end{array}$ & $\begin{array}{l}\text { S. carpocapsae } \\
(\text { EGAZ9) }\end{array}$ & $\begin{array}{l}\text { S. carpocapsae } \\
(\text { EGAZ10) }\end{array}$ \\
\hline $\mathrm{Al}$ & $0.18 \pm 0.07 \mathrm{a}$ & $0.26 \pm 0.12 \mathrm{a}$ & $0.19 \pm 0.05 \mathrm{a}$ & $0.22 \pm 0.1 \mathrm{a}$ & $0.18 \pm 0.05 \mathrm{a}$ & $0.18 \pm 0.09 \mathrm{a}$ & $0.16 \pm 0.05 \mathrm{a}$ \\
$\mathrm{Cr}$ & $1.88 \pm 0.55 \mathrm{a}$ & $1.85 \pm 0.50 \mathrm{a}$ & $1.45 \pm 0.50 \mathrm{a}$ & $1.27 \pm 0.40 \mathrm{a}$ & $1.21 \pm 0.60 \mathrm{a}$ & $1.32 \pm 0.50 \mathrm{a}$ & $1.58 \pm 0.30 \mathrm{a}$ \\
$\mathrm{Pb}$ & $1.37 \pm 0.40 \mathrm{a}$ & $2.03 \pm 0.80 \mathrm{a}$ & $1.48 \pm 0.45 \mathrm{a}$ & $1.7 \pm 0.5 \mathrm{a}$ & $1.31 \pm 0.35 \mathrm{a}$ & $1.1 \pm 0.25 \mathrm{a}$ & $1.64 \pm 0.75 \mathrm{a}$ \\
$\mathrm{Cd}$ & $1.27 \pm 0.41 \mathrm{a}$ & $0.49 \pm 0.15 \mathrm{~b}$ & $0.32 \pm 0.15 \mathrm{~b}$ & $1.34 \pm 0.40 \mathrm{a}$ & $0.45 \pm 0.17 \mathrm{~b}$ & $0.46 \pm 0.20 \mathrm{~b}$ & $0.61 \pm 0.21 \mathrm{~b}$ \\
$\mathrm{Se}$ & $0.19 \pm 0.07 \mathrm{a}$ & $0.22 \pm 0.06 \mathrm{a}$ & $0.14 \pm 0.05 \mathrm{abc}$ & $0.20 \pm 0.05 \mathrm{a}$ & $0.16 \pm 0.04 \mathrm{ac}$ & $0.10 \pm 0.04 \mathrm{bc}$ & $0.17 \pm 0.05 \mathrm{ac}$ \\
$\mathrm{Zn}$ & $8.00 \pm 1.20 \mathrm{a}$ & $4.12 \pm 0.80 \mathrm{~b}$ & $4.63 \pm 0.90 \mathrm{~b}$ & $4.63 \pm 0.90 \mathrm{~b}$ & $5.08 \pm 1.30 \mathrm{~b}$ & $3.4 \pm 0.60 \mathrm{~b}$ & $3.25 \pm 0.50 \mathrm{~b}$ \\
$\mathrm{Mn}$ & $15.1 \pm 5.0 \mathrm{a}$ & $6.10 \pm 3.5 \mathrm{~b}$ & $27.4 \pm 6.0 \mathrm{c}$ & $4.10 \pm 2.0 \mathrm{~b}$ & $6.50 \pm 2.5 \mathrm{~b}$ & $15.1 \pm 3.8 \mathrm{a}$ & $16.3 \pm 3.2 \mathrm{a}$ \\
$\mathrm{Co}$ & $16.6 \pm 3.5 \mathrm{a}$ & $19.01 \pm 4.0 \mathrm{a}$ & $19.9 \pm 5.8 \mathrm{a}$ & $18 \pm 5.0 \mathrm{a}$ & $10.7 \pm 2.5 \mathrm{~b}$ & $9.68 \pm 2.0 \mathrm{~b}$ & $12.6 \pm 1.0 \mathrm{~b}$ \\
$\mathrm{Fe}$ & $43.7 \pm 7.5 \mathrm{a}$ & $31.2 \pm 5.0 \mathrm{a}$ & $29.4 \pm 6.2 \mathrm{a}$ & $38.4 \pm 6.5 \mathrm{a}$ & $20.3 \pm 3.9 \mathrm{~b}$ & $12.5 \pm 8.0 \mathrm{~b}$ & $16.6 \pm 7.0 \mathrm{~b}$ \\
$\mathrm{Cu}$ & $62.5 \pm 12.5 \mathrm{a}$ & $44.2 \pm 8.5 \mathrm{a}$ & $40.5 \pm 6.0 \mathrm{a}$ & $49.5 \pm 8.0 \mathrm{a}$ & $31.8 \pm 4.4 \mathrm{~b}$ & $23.9 \pm 3.8 \mathrm{~b}$ & $28.6 \pm 4.5 \mathrm{~b}$ \\
\hline
\end{tabular}

Values followed by different lowercase letters in the same row are significantly different $(P<0.05)$

Jaworska et al. (1997a) mentioned that $\mathrm{Fe}$ and $\mathrm{Cu}$ ions vitalized IJs of Heterorhabditis bacteriophora and increased their mobility and pathogenic abilities which could support our findings. One explanation for the high level of $\mathrm{Cu}$ concentration in all the studied EPN isolates is that nematodes during their early stages inside the insect body collect and accumulate $\mathrm{Cu}$ from the surrounding $\mathrm{Cu}$-rich insect hemolymph (Malik and Malik, 2009). However this explanation does not elucidate the significant difference in $\mathrm{Cu}$ concentration between the two nematode families. Another plausible explanation is that $\mathrm{Cu}$ accumulation in IJs could be due to bacteria associated with EPN, for which $\mathrm{Cu}$ is known to be an essential trace element (Kuzuya and Inouye, 2001; Massaoud et al., 2011). The nematode bacteria of Photorhabdus for Heterorhabditis spp. and Xenorhab$d u s$ for the Steinernema spp. produce a range of activities, including hydrolytic enzymes, that converting the insects' internal organs and tissues into bacterial biomass (Watson et al., 2010). Photorhabdus secreted more than four proteases such as PrtA peptidase, PhpC (Photorhabdus protease $\mathrm{C}$ ), thermolysin-like enzymes, and other enzymes that may be used in the suppression of the immune

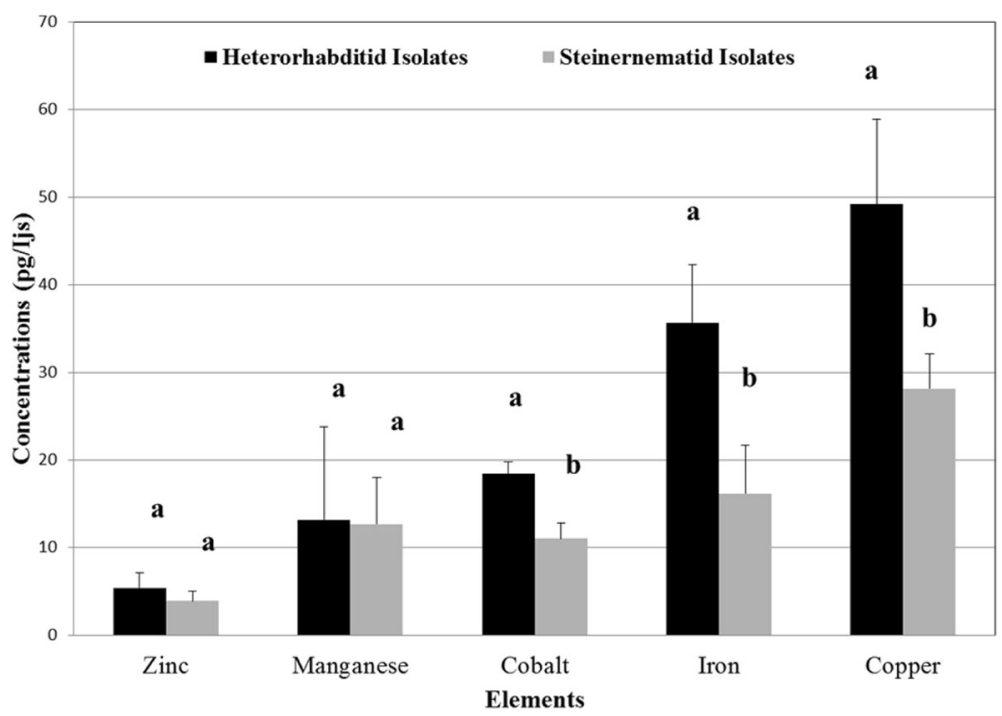

Fig. 1 Variations of cobalt, manganese, zinc, iron, and copper contents (mean \pm SD) between the infective juveniles of heterorhabditid and steinernematid isolates (adjacent bars with different letters are significantly different, $P<0.05$ ) 


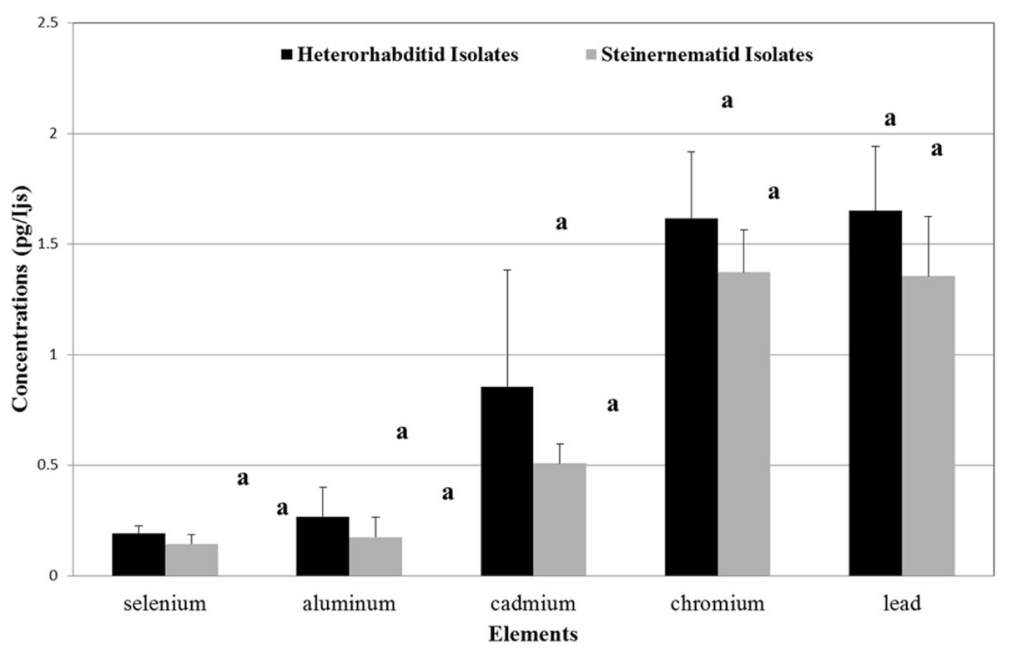

Fig. 2 Variations of lead, chromium, cadmium, aluminum, and selenium contents (mean \pm SD) between the infective juveniles of heterorhabditid and steinernematid isolates (adjacent bars with the same letter are not significantly different, $P>0.05$ )

responses, while only one proteolytic enzyme (protease B) has been partially characterized in Xenorhabdus strains (Massaoud et al., 2010, 2011). Although thermolysin-like enzymes are related to zinc metalloenzymes, it was found that $\mathrm{Cu}$ and $\mathrm{Co}$ ions increased their activities to $200 \%$ of their original one, while $\mathrm{Zn}$ alone is insufficient (Holmquist and Vallee, 1974; Kuzuya and Inouye, 2001 and Massaoud et al., 2011). Thus, it could be concluded that Photorhabdus bacteria of Heterorhabditis spp. accumulate $\mathrm{Cu}$ and $\mathrm{Co}$ for activation of their metalloenzymes to enhance their virulence. This conclusion could be supported by the finding that concentrations of $\mathrm{Cu}$ and $\mathrm{Co}$ ions in nematode isolates related to heterorhabditid EPN family were significantly higher than the ones related to Steinernematidae family lacking of Photorhabdus bacteria. The uptake of Photorhabdus bacteria associated with Heterorhabditidae EPN to Fe could also explain the detected high concentrations of Fe ions in IJs and also explains their significant higher concentration in nematode isolates related to Heterorhabditidae family than concentration in isolates related to Steinernematidae family in the present study. Iron is an essential nutrient for bacteria that have different mechanisms for obtaining both the ferrous $(\mathrm{Fe} 2+)$ and ferric $(\mathrm{Fe} 3+)$ forms of this metal from their environments. Watson et al. (2010) constructed P. luminescens mutant bacteria that was predicted to be crippled in its ability to obtain Fe3+ from surrounding. They found that this mutant does not grow well in iron-limited media and lost their ability to kill insects and concluded that $\mathrm{Fe}++$ was essential for P. luminescens bacteria of Heterorhabditidae-related nematodes. However, further experiments might determine whether $\mathrm{Cu}, \mathrm{Fe}$, and $\mathrm{Co}$ are concentrated in IJs or in bacteria associated with the EPNs.

\section{Conclusions}

In all of tested isolates of Entomopathogenic Nematodes, the content of $\mathrm{Cu}$ was the highest and that of Se was the lowest. The concentrations of the studied elements were in the following descending order: $\mathrm{Cu}>\mathrm{Fe}>\mathrm{Co}>\mathrm{Mn}>$ $\mathrm{Zn}>\mathrm{Pb}>\mathrm{Cr}>\mathrm{Cd}>\mathrm{Al}>\mathrm{Se}$. It is suggested that Photorhabdus bacteria associated with Heterorhabditis spp of EPN accumulate $\mathrm{Cu}, \mathrm{Fe}$ and $\mathrm{Co}$ for activation of their metalloenzymes to enhance their virulence potential. However, further experiments might determine whether $\mathrm{Cu}, \mathrm{Fe}$, and $\mathrm{Co}$ are concentrated in IJs or in bacteria associated with the EPNs.

\section{Acknowledgements}

I would like to thank the Deanship of Scientific Research, King Faisal University, Saudi Arabia, for their support (project no. 130025). And also, I would like to thank Prof. Dr. Monzer Abd-Elrahman and Prof. Dr. Ahmed Azazy, Plant

Protection Research Institute PPRI, Physiology Department, Agricultural Research Center ARC, Egypt, for their kind cooperation in conducting this valuable study.

\section{Competing interests}

The author declares that they have no competing interests.

\section{Publisher's Note}

Springer Nature remains neutral with regard to jurisdictional claims in published maps and institutional affiliations.

Received: 12 September 2017 Accepted: 6 December 2017 Published online: 30 January 2018

\section{References}

Costat (2008) Statistical software package. CoHort Software Inc., Berkeley version 6.45. www.cohort.com

El-Bahr SM, Abdelghany AM (2015) Heavy metal and trace element contents in edible muscle of three commercial fish species, and assessment of possible risks associated with their human consumption in Saudi Arabia. J Adv Vet Anim Res 2(3):1-8

Holmquist B, Vallee BL (1974) Metal substitutions and inhibition of thermolysin: spectra of the cobalt enzyme. Biol Chem 249:4601-4607 
Jaworska M, Gorczyca A (1993) Effect of manganese ions on entomopathogenic nematodes. Entomon 2(4):518-519

Jaworska M, Gorczyca A (2002) The effect of metal ions on mortality, pathogenicity and reproduction of entomopathogenic nematodes Steinernema feltiae Filipjev (Rhabditida, Steinernematidae). Pol J Environ Stud 11(5):517-519

Jaworska M, Gorczyca A (2009) Effect of manganese ions on beneficial organisms. J Elem 14(2):257-263

Jaworska M, Gorczyca A, Sepiol J, Szeliga E, Tomsik P (1997a) Effect of metal ions on the entomopathogenic nematode Heterorhabditis bacteriophora Poinar (Nematoda: Heterorhabditidae) under laboratory condtions. Water Air Soil Pollut 93:157-166

Jaworska, M.; A. Gorczyca; J. Sepiol, E. Szeliga and P. Tomsik. 1997b. Metal-metal interaction in biological systems. Part V. Steinernema carpocapsae (Stinernematidae) and Heterorhabditis bacteriophora (Heterorhabditidae) entomopathogenic nematodes. Water Air Soil Pollut, 93:213-223, 1997

Kaya HK, Stock SP (1997) Techniques in insect nematology. In: Lacey LA (ed) Manual of techniques in insect pathology. Academic Press, London, pp 281-324

Kuzuya K, Inouye K (2001) Effects of cobalt-substitution of the active zinc ion in thermolysin on its activity and active-site microenvironment. J Biochem 130(6):783-788

Malik A, Malik MA (2009) Variation in metal ion concentrations in the haemolymph of the silkworm, Bombyx mori during development. Acad J Entomol (AJE) 2(1):10-15

Massaoud MK, Marokházi J, Fodor A, Venekei I (2010) Proteolytic enzyme production by strains of the insect pathogen Xenorhabdus and characterization of an early-log-phase-secreted protease as a potential virulence factor. Appl Environ Microbiol 76(20):6901-6909

Massaoud MK, Marokházi J, Venekei I (2011) Enzymatic characterization of a serralysin-like metalloprotease from the entomopathogen bacterium, Xenorhabdus. Biochim Biophys Acta 1814(10):1333-1339

Nachev M, Schertzinger G, Sures B (2013) Comparison of the metal accumulation capacity between the acanthocephalan Pomphorhynchus laevis and larval nematodes of the genus Eustrongylides sp. infecting barbel (Barbus barbus). Parasit. Vectors 36:21-29

Nguyen KB (2007) Methodology, morphology and identification. In: Nguyen KB, Hunt DJ (eds) Entomopathogenic nematodes: systematics, phylogeny and bacterial symbionts. Nematology monographs and perspectives, vol Vol. 5. Brill, Leiden-Boston, pp 59-119

Pakshirajan K, Worku AN, Acheampong MA, Lubberding HJ, Lens PN (2013) Cr (III) and $\mathrm{Cr}(\mathrm{VI})$ removal from aqueous solution by cheaply available fruit waste and algal biomass. Biotechnol Appl Biochem 170:498-513

Sambongi Y, Nagae T, Liu Y, Yoshimizu T, Takeda K, Wada Y, Futai M (1999) Sensing of cadmium and copper ions by externally exposed ADL, ASE, and ASH neurons elicits avoidance response in Caenorhabditis elegans. Neuroreport 10:753-757

Sun Y, Bai G, Wang Y, Zhang Y, Pan J, Cheng W, Feng X, Li H, Ma C, Ruan W, Shapiro D (2016) The impact of $\mathrm{Cu}, \mathrm{Zn}$ and $\mathrm{Cr}$ salts on the relationship between insect and plant parasitic nematodes: a reduction in biocontrol efficacy. Appl Soil Ecol 107:108-115

Watson RJ, Millichap P, Joyce SA, Reynolds S, Clarke DJ (2010) The role of iron uptake in pathogenicity and symbiosis in Photorhabdus luminescens TT01. BMC Microbiol 22(10):177-200

\section{Submit your manuscript to a SpringerOpen ${ }^{\circ}$ journal and benefit from:}

- Convenient online submission

- Rigorous peer review

- Open access: articles freely available online

- High visibility within the field

- Retaining the copyright to your article

Submit your next manuscript at $\gg$ springeropen.com 